\title{
PENERAPAN TEKNOLOGI PEMISAHAN MENINGKATKAN PRODUKSI MINYAK KEMIRI DIDESA BATUDULANG KACAMATAN BATULANTEH SUMBAWA
}

\author{
Emsal Yanuar $^{1 *}$, Wirya Sarwana ${ }^{2}$, Sudrajat Martadinata ${ }^{3}$, Kiki Firanita ${ }^{1}$, Ihsanul Huda ${ }^{1}$ \\ ${ }^{1}$ Program Studi Teknik Metalurgi, Fakultas Teknik, Universitas Teknologi Sumbawa \\ ${ }^{2}$ Program Studi Teknik Mesin, Fakultas Teknik, Universitas Teknologi Sumbawa \\ ${ }^{3}$ Program Studi Akuntansi, Fakultas Ekonomi dan Bisnis, Universitas Teknologi Sumbawa \\ ${ }^{*}$ Co-Author: emsal.yanuar@uts.ac.id
}

\begin{abstract}
ABSTRAK. Desa Batudulang adalah salah satu desa di Kecamatan Batulanteh yang memiliki potensi tanaman kemiri. Sejauh ini, biji kemiri telah digunakan oleh kelompok KUB Sumber Alam untuk memproduksi minyak kemiri, kegiatan ini telah menjadikan desa Batudulang sebagai desa penghasil minyak kemiri pertama di Pulau Sumbawa dan bahkan di NTB. Fokus kegiatan pengabdian masyarakat adalah meningkatkan kemampuan kelompok bisnis untuk mengurangi waktu produksi minyak kemiri. Waktu produksi dikurangi dengan menerapkan teknologi pengeringan matahari untuk mengeringkan biji kemiri, penyaringan cepat untuk memisahkan minyak dari ampas biji kemiri menggunakan corong vakum dan di ikuti dengan proses pengemasan. Penggunaan solar drier dalam proses pengeringan biji kemiri memerlukan waktu sekitar dua hari, yang awalnya tanpa menggunakan solar drier membutuhkan waktu sekitar 8-10 hari. Kemudian kemiri ditekan oleh mesin hidrolik untuk mendapatkan minyak kemiri. Minyak kemiri yang dihasilkan masih memiliki partikel, sehingga harus disaring menggunakan vakum Buchner. Dalam proses ini, waktu produksi berkurang menjadi 1 hari dari sebelumnya perlu dipraktekkan 8 hari. Dengan menerapkan teknologi pengeringan matahari untuk mengeringkan biji hazelnut, penyaringan cepat untuk memisahkan minyak menggunakan saluran vakum diikuti dengan proses pengemasan dapat mengurangi waktu produksi minyak kemiri menjadi 3 hari yang sebelumnya membutuhkan waktu sekitar 16 hari.
\end{abstract}

Kata Kunci: Desa Batudulang, Minyak kemiri, waktu produksi, Batudulang,solar drier, corong Buchner

ABSTRACT. Batudulang Village is one of the villages in the Batulanteh SubDistrict that has the potential of candlenut plants. For distant, hazelnut seeds have been used by the Sumber Alam group to produce candlenut oil. This activity has made Batu Dulang village as the first candlenut producing village on Sumbawa Island and even in NTB. The focus of community service activities is to increase group abilities to reduce the time of production of candlenut oil. Production time is reduced by applying solar drying technology to dry candlenut seeds, quick filtering to separate oil from candlenut pulp using a vacuum funnel, and followed by the packaging process. The use of solar drier to remove the water contains the hazelnut seeds that needed about two days, whereas initially without solar drier required about 8-10 days. Then the hazelnut is pressed by a hydraulic machine to get hazelnut oil. The resulting hazelnut oil still has particles, so it must be filtered using a Buchner vacuum. In this process, the production time is reduced to 1 day from the past 8 days needs to be practiced. By applying solar drying technology to dry the hazelnut seeds, rapid filtering to separate the oil using a vacuum channel followed by the packaging process can reduce the time of the production of candlenut oil to 3 days than before about 16 days. 
Keywords: Batudulang Village, candlenut oil, production time, solar drier, buchner funnel

\section{PENDAHULUAN}

Desa Batu Dulang merupakan salah satu desa di kecamatan Batulanteh yang berada ditengah nuansa alam dengan banyaknya potensi yang dimilikinya. Desa Batu Dulang dapat diakses dengan mudah menggunakan kendaraan roda dua maupun roda empat dengan jarak sekitar $27 \mathrm{~km}$ dari pusat Kota Sumbawa dan sekitar $37 \mathrm{~km}$ dari Perguruan Tinggi Universitas Teknologi Sumbawa (UTS). Desa Batu Dulang memiliki potensi alam melimpah berupa pohon kemiri. Sejauh ini, biji kemiri telah dimanfaatkan oleh kelompok KUB Sumber Alam sehingga menjadikan Desa Batu Dulang sebagai desa penghasil minyak kemiri pertama di pulau Sumbawa bahkan di NTB. Menurut Estrada (2007) bahwa pohon kemiri mampu menghasilkan sekitar $80 \mathrm{~kg}$ kemiri/pohon setiap tahun [1]. Kandungan minyak dalam biji kemiri tergolong tinggi yakni sekitar 55\%-66\% berat minyak [2].

Saat ini, minyak kemiri yang diperoleh melalui pengolahan pasca panen telah dipasarkan hingga tingkat regional dan nasional [3]. Walaupun demikian, KUB Sumber alam masih sulit memenuhi permintaan pasar dan tak jarang permintaan pasar ada yang tak terpenuhi. Hal ini disebabkan karena KUB sumber alam masih minimnya pengetahuan tentang pemanfaatan teknologi tepat guna dalam melakukan proses pemisahan minyak kemiri. Proses produksi yang dilakukan oleh KUB Sumber alam masih tergolong tradisional dan masih minimnya peran teknologi untuk produksi minyak kemiri. Hal ini tidak terlepas dari pengalaman dan pengetahuan sumber daya manusia yang dimiliki oleh KUB Sumber Alam. Berdasarkan survey yang telah dilakukan, KUB Sumber Alam mampu menghasilkan 120 botol kemasan $60 \mathrm{~mL}$ dalam sekali produksi dengan waktu proses pengolahan sekitar 16 hari. Pada proses pengeringan memerlukan waktu sekitar 8-10 hari, proses pengendapan memerlukan waktu 8-10 hari, dan proses pemisahan serta pemurnian dapat dilakukan sehari. Dari serangkaian proses yang dilalui maka dapat disimpulkan proses produksi membutuhkan waktu sekitar 16 hari yang tergolong memakan waktu produksi yang lama.

Waktu proses produksi yang diperlukan tergolong cukup lama dibandingkan dengan permintaan pasar yang semakin meningkat. Hal tersebut akan menjadi sebuah ancaman bagi keberlanjutan usaha akibat ketidakmampuan produsen dalam memenuhi permintaan pasar. Oleh karena itu, pada kegiatan pengabdian ini fokus untuk meningkatkan kemampuan kelompok usaha dalam melakukan proses pemisahan dan pemurnian minyak kemiri menggunakan teknologiteknologi pemisahan minyak kemiri.

\section{ANALISIS PERMASALAHAN}

Proses produksi minyak kemiri di Desa Batu Dulang yang dilakukan oleh KUB Sumber alam masih tergolong tradisional melalui serangkaian proses meliputi proses pengeringan, pengendapan dan pemisahan minyak yang membutuhkan waktu sekitar 16 hari. Permasalahan yang dihadapi oleh KUB Sumber Alam yaitu permasalahan pada proses produksi yakni masih membutuhkan waktu lama, sehingga akan mempengaruhi jumlah produksi. Waktu produksi yang lama bisa mengakibatkan tidak bisa terpenuhi permintaan pasar minyak kemiri. Adapun solusi yang telah dilakukan yakni meningkatkan kemampuan kelompok usaha dalam menerapkan teknologi pemisahan untuk meningkatkan produksi minyak biji kemiri melalui konsep pemberdayaan 
masyarakat. Solusi yang ditawarkan dirumuskan secara sistematis berdasarkan tahapan produksi minyak kemiri yakni dengan cara memangkas waktu produksi menggunakan teknologi solar drier untuk mengeringkan biji kemiri, pengepresan menggunakan alat hidrolik dan penyaringan menggunakan corong Buchner.

\section{TUJUAN DAN MANFAAT}

Kegiatan ini bertujuan untuk meningkatkan kemampuan anggota kelompok usaha dalam menggunakan teknologi pemisahan minyak kemiri dan menurunnya waktu produksi minyak kemiri

\section{METODE PELAKSANAAN}

Metode pelaksanaan program dalam mengatasi permasalahan produksi dilakukan beberapa tahapan sebagai berikut :

a. Sosialisasi tentang rencana Kegiatan Pengabdian Kepada masyarakat.

Kegiatan ini bertujuan untuk memberikan infromasi kepada mitra tentang akan adanya kegiatan kegiatan pengabdian kepada masyarakat, hal ini dilakukan setelh danya pengumuman hasil seleksi proposal pengabdian kepada masyarakat.

b. Penyampaian materi awal tentang IPTEK yang akan digunakan pada kegiatan Pengabdian Kepada masyarakat.

Penyampaian materi awal tentang IPTEK yang digunakan bertujuan untukmemberikan informasi teknologi-teknologi yang akan digunakan digunakan secara jelas.Kegiatan ini dilakukan menggunakan metode diskusi antara tim pengusul dan mitra

c. Pembuatan TTG solar drier

Kegiatan ini merupakan tindak lanjut atau implementasi dari kegiatan pemaparan materi IPTEK. TTG solar drier berfungsi sebagai alat pengering biji kemiri. Alat ini diharapkan dapat menurunkan waktu pengeringan biji kemiri.

d. Pelatihan dan Workshop pemisahan dan Pemurnian Minyak Kemiri

Pelatihan dan workshop ini bertujuan untuk meningkat kemampuan mitra dalam menggunakan teknologi-teknologi yang digunakan pada proses produksi minyak kemiri.

\section{HASIL DAN PEMBAHASAN}

Kegiatan sosialisasi kegiatan pengabdian kepada masyarakat mendapat sambutan baik dari kelompok Usaha didesa Batu Dulang. Hal ini dibuktikan dengan terjalinnya kerjasama antara pelaksana dan mitra kegiatan pengabdian kepada masyarakat, misalnya mitra memberikan informasi-informasi terkait dengan kondisi usaha, sedangkan pelaksana merumuskan solusi dari permasalahan yang dihadapi oleh mitra. Penyampaian materi awal tentang IPTEK yang digunakan bertujuan untuk memberikan informasi teknologi-teknologi yang akan digunakan digunakan secara jelas. Teknologi-teknologi yag akan digunakan dalam kegiatan ini diperkenalkan mengenai nama teknologi, prinsip kerja teknologi dan penggunaan teknologi. Para kelompok usaha bersama di Desa Batudulang belum mengetahui tentang teknologi-teknologi yang bisa digunakan dalam proses pemisahan minyak kemiri. Setelah kegiatan ini, para anggota kelompok telah mengetahui tentang nama, prinsip dan cara menggunakan teknologi seperti solar drier, vakum Buchner dan corong pisah. 
Pembuatan teknologi tepat guna solar drier ini bertujuan untuk mempercepat proses pengeringan biji kemiri (Gambar 1). Berdasarkan hasil uji coba, bahwa penggunaan solar dapat mengeringkan biji kemiri selama dua hari. Waktu penjemuran ini lebih cepat dibandingkan dengan menggunakan pengeringan lantai dan oven. Buah kemiri sudah siap dikupas ketika setelah dijemur setelah 2 hari, hasil ini jauh lebih cepat jika dibandingkan dengan penjemuran menggunakan lantai yang membutuhkan sekitar 8-10 hari. Hal ini disebabkan karena suhu reactor pada solar drier bisa mencapai $80^{\circ} \mathrm{C}$ (Gambar 2), sehingga kandungan air dapat hilang atau menguap. Suhu ini sudah sesuai dengan kondisi biji kemiri, dimana suhu ini tidak terlalu tinggi sehingga kondisi biji kemiri masih bisa menghasilkan minyak kemiri dengan kulitas baik.



Gambar 1. Solar drier untuk menjemur biji kemiri 


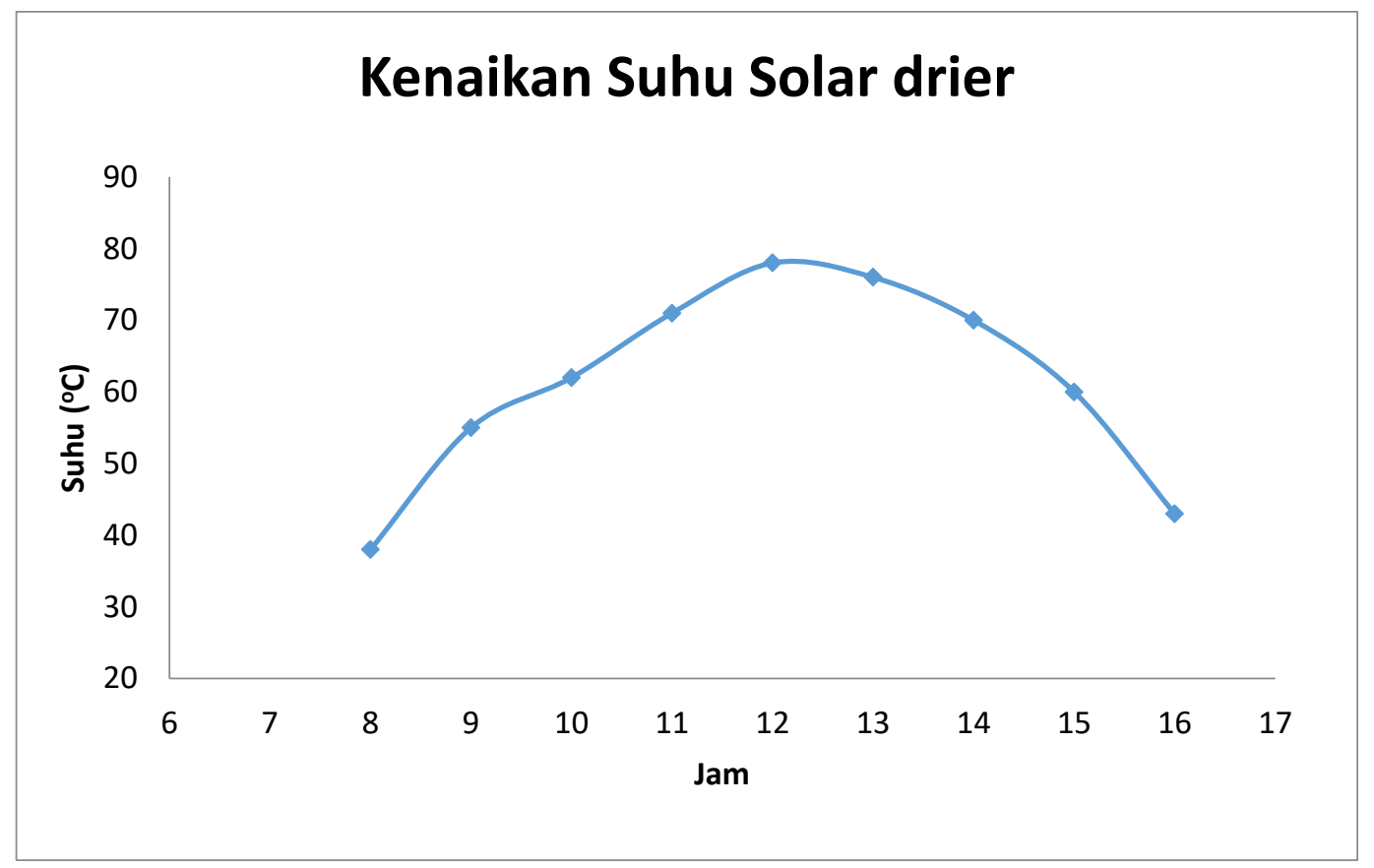

Gambar 2. Kenaikan suhu solar drier

Selain itu, pada kegiatan ini juga dilakukan pelatihan dan workshop untuk meningkat kemampuan mitra dalam menggunakan teknologi-teknologi yang digunakan pada proses produksi minyak kemiri. Sejauh ini, kelompok usaha sudah memahami dan dapat menggunakan alat atau teknologi pemisahan secara mandiri. Hal ini dikarenakan teknologi yang diterapkan sangat sederhana dan mudah dipahami oleh masyarakat. Secara umum masyarakat sudah bisa menggunakan dan memahami prinsip kerja dari teknologi solar drier, vakum Buchner dan corong pisah. Masyarakat telah mencoba menerapkan teknologi-teknologi ini untuk produksi minyak kemiri. Sebelum menerapkan teknologi tersebut waktu yang dibutuhkan untuk memproduksi minyak kemiri yakni sekitar 16 hari, namun setelah menggunakan teknologi-teknologi tersebut menjadi 3 hari (gambar 3). Secara partial, solar drier dapat memangkas waktu penjemuran yakni dari 8-10 menjadi 2 hari, sedangkan untuk vakum Buchner dari 6 hari menjadi kurang dari satu hari, yakni sekitar 1 hari untuk memisahkan partikulat dari minyak kemiri. Hal ini disebabkan karena secara prinsip vakum Buchner terdiri dari dua bagian yaitu penyedot udara dan saringan. Ketika mesin ini dioperasikan maka akan mempercepat proses pemisahan-pemisahan partikulat dengan minyak kemiri. Minyak yang dihasilkan selanjutnya dilakukan pengemasan untuk dijual di masyarakat.

\section{KESIMPULAN}

Peningkatan kemampuan kelompok usaha untuk pemisahan minyak kemiri di Desa Batu Dulang Kecamatan Batulanteh telah berhasil dilakukan. Waktu produksi kemiri berhasil dipangkas yang sebelumnya 16 hari menjadi 3 hari. Dengan menerapkan teknologi solar drier untuk mengeringkan biji kemiri, penyaringan cepat untuk memisahkan ampas biji dengan minyak 
menggunakan corong vakum dilanjutkan dengan proses pengemasan dapat mempercepat proses dan meningkatkan jumlah produksi minyak kemiri.

\section{UCAPAN TERIMAKASIH}

Pada kesempatan ini, Penulis mengucapkan terima kasih kepada Kementerian Riset dan Teknologi, Indonesia yang telah memberikan dukungan pendanaan melalui dana hibah pengabdian kepada masyarakat program kemitraan stimulus, selain itu kami ucapkan terimakasih juga kepada Universitas Teknologi Sumbawa dan Kelompok Usaha Bersama (KUB) Desa Batudulang, Kecamatan Batulanteh, Kabupaten Sumbawa, NTB yang telah membantu kegiatan pengabdian ini sehingga dapat berlangsung baik.

\section{DAFTAR PUSTAKA}

[1] Estrada, F. 2007. Pengambilan Minyak Kemiri Dengan Cara Pengepressan dan Dilanjutkan Ekstraksi Cake Oil. Widya Teknik .Vol 7 (2): 121-130.

[2] Chynintya, G., dan Paramita, Vita. 2016. Pengaruh Temperatur, Kecepatan Putar Ulir dan Waktu Pemanasan Awal Terhadap Perolehan Minyak Kemiri Dari Biji Kemiri Dengan Metode Penekanan Mekanis (Screw Press). Metana. Vol. 12 (1): 17-25.

[3] Hakim, Lukman. 2018. Kajian Analisis One Village One Product (OPOV) Kabupaten Sumbawa. Jurnal Riset Kajian Teknologi dan Lingkungan. Vol.1 (1): 1-9. 